University of Nebraska - Lincoln

DigitalCommons@University of Nebraska - Lincoln

\title{
Comparison of total mercury and methylmercury cycling at five sites using the small watershed approach
}

James B. Shanley

U.S. Geological Survey, jshanley@usgs.gov

\section{Alisa Mast}

U.S. Geological Survey, mamast@usgs.gov

Donald H. Campbell

U.S. Geological Survey, dhcampbe@usgs.gov

George R. Aiken

U.S. Geological Survey, graiken@usgs.gov

David P. Krabbenhoft

U.S. Geological Survey, dpkrabbe@usgs.gov

See next page for additional authors

Follow this and additional works at: https://digitalcommons.unl.edu/usgsstaffpub

Part of the Earth Sciences Commons

Shanley, James B.; Mast, M. Alisa; Campbell, Donald H.; Aiken, George R.; Krabbenhoft, David P.; Hunt, Randall J.; Walker, John F.; Schuster, Paul F.; Chalmers, Ann; Aulenbach, Brent T.; Peters, Norman E.; Marvin-DiPasquale, Mark; Clow, David W.; and Shafer, Martin M., "Comparison of total mercury and methylmercury cycling at five sites using the small watershed approach" (2008). USGS Staff -- Published Research. 441.

https://digitalcommons.unl.edu/usgsstaffpub/441

This Article is brought to you for free and open access by the US Geological Survey at DigitalCommons@University of Nebraska - Lincoln. It has been accepted for inclusion in USGS Staff -- Published Research by an authorized administrator of DigitalCommons@University of Nebraska - Lincoln. 


\section{Authors}

James B. Shanley, M. Alisa Mast, Donald H. Campbell, George R. Aiken, David P. Krabbenhoft, Randall J. Hunt, John F. Walker, Paul F. Schuster, Ann Chalmers, Brent T. Aulenbach, Norman E. Peters, Mark MarvinDiPasquale, David W. Clow, and Martin M. Shafer 


\title{
Comparison of total mercury and methylmercury cycling at five sites using the small watershed approach
}

\author{
James B. Shanley ${ }^{\mathrm{a}, *}$, M. Alisa Mast ${ }^{\mathrm{b}}$, Donald H. Campbell ${ }^{\mathrm{b}}$, George R. Aiken ${ }^{\mathrm{c}}$, \\ David P. Krabbenhoft ${ }^{d}$, Randall J. Hunt ${ }^{d}$, John F. Walker ${ }^{d}$, Paul F. Schuster ${ }^{c}$, \\ Ann Chalmers ${ }^{a}$, Brent T. Aulenbach ${ }^{\mathrm{e}}$, Norman E. Peters ${ }^{\mathrm{e}}$, \\ Mark Marvin-DiPasquale ${ }^{\mathrm{f}}$, David W. Clow ${ }^{\mathrm{b}}$, Martin M. Shafer ${ }^{\mathrm{g}}$ \\ ${ }^{a}$ US Geological Survey, PO Box 628, Montpelier, VT 05601, USA \\ ${ }^{\mathrm{b}}$ US Geological Survey, MS 415 Denver Federal Center, Denver, CO 80225, USA \\ ${ }^{c}$ US Geological Survey, 3215 Marine Street, Suite E-127, Boulder, CO 80303, USA \\ ${ }^{\mathrm{d}}$ US Geological Survey, 8505 Research Way, Middleton, WI 53562, USA \\ ${ }^{\mathrm{e}}$ US Geological Survey, 3039 Amwiler Road, Suite 130, Atlanta, GA 30360, USA \\ ${ }^{\mathrm{f}}$ US Geological Survey, 345 Middlefield Rd., MS 480, Menlo Park, CA 94025, USA \\ ${ }^{\mathrm{g}}$ Environmental Chemistry \& Technology and Wisconsin State Laboratory of Hygiene, University of Wisconsin, Madison, WI 53706, USA
}

Received 13 December 2007; accepted 13 December 2007

High-flow sampling reveals strong contrasts in total mercury and methylmercury cycling in five diverse USA watersheds.

\begin{abstract}
The small watershed approach is well-suited but underutilized in mercury research. We applied the small watershed approach to investigate total mercury ( $\mathrm{THg}$ ) and methylmercury $(\mathrm{MeHg})$ dynamics in streamwater at the five diverse forested headwater catchments of the US Geological Survey Water, Energy, and Biogeochemical Budgets (WEBB) program. At all sites, baseflow THg was generally less than $1 \mathrm{ng} \mathrm{L}^{-1}$ and $\mathrm{MeHg}$ was less than $0.2 \mathrm{ng} \mathrm{L}{ }^{-1}$. THg and $\mathrm{MeHg}$ concentrations increased with streamflow, so export was primarily episodic. At three sites, $\mathrm{THg}$ and $\mathrm{MeHg}$ concentration and export were dominated by the particulate fraction in association with POC at high flows, with maximum $\mathrm{THg}(\mathrm{MeHg})$ concentrations of $94(2.56) \mathrm{ng} \mathrm{L}^{-1}$ at Sleepers River, Vermont; $112(0.75) \mathrm{ng} \mathrm{L}^{-1}$ at Rio Icacos, Puerto Rico; and 55 (0.80) ng L $\mathrm{L}^{-1}$ at Panola Mt., Georgia. Filtered $(<0.7 \mu \mathrm{m})$ THg increased more modestly with flow in association with the hydrophobic acid fraction (HPOA) of DOC, with maximum filtered THg concentrations near $5 \mathrm{ng} \mathrm{L}^{-1}$ at both Sleepers and Icacos. At Andrews Creek, Colorado, THg export was also episodic but was dominated by filtered $\mathrm{THg}$, as POC concentrations were low. MeHg typically tracked $\mathrm{THg}$ so that each site had a fairly constant $\mathrm{MeHg} / \mathrm{THg}$ ratio, which ranged from near zero at Andrews to $15 \%$ at the low-relief, groundwater-dominated Allequash Creek, Wisconsin. Allequash was the only site with filtered $\mathrm{MeHg}$ consistently above detection, and the filtered fraction dominated both $\mathrm{THg}$ and $\mathrm{MeHg}$. Relative to inputs in wet deposition, watershed retention of $\mathrm{THg}$ (minus any subsequent volatilization) was $96.6 \%$ at Allequash, $60 \%$ at Sleepers, and $83 \%$ at Andrews. Icacos had a net export of $\mathrm{THg}$, possibly due to historic gold mining or frequent disturbance from landslides. Quantification and interpretation of $\mathrm{Hg}$ dynamics was facilitated by the small watershed approach with emphasis on event sampling.
\end{abstract}

(C) 2008 Elsevier Ltd. All rights reserved.

Keywords: Total mercury; Methylmercury; Episodic transport; Watershed

\footnotetext{
* Corresponding author. Tel.: +1 802828 4466; fax: +1 8028284465 .

E-mail addresses: jshanley@usgs.gov (J.B. Shanley), mamast@usgs.gov (M. Alisa Mast), dhcampbe@usgs.gov (D.H. Campbell), graiken@usgs.gov (G.R. Aiken), dpkrabbe@usgs.gov (D.P. Krabbenhoft), rjhunt@usgs.gov (R.J. Hunt), jfwalker@usgs.gov (J.F. Walker), pschuste@usgs.gov (P.F. Schuster), chalmers@usgs.gov (A. Chalmers), btaulenb@usgs.gov (B.T. Aulenbach), nepeters@usgs.gov (N.E. Peters), mmarvin@usgs.gov (M. Marvin-DiPasquale), dwclow@usgs.gov (D.W. Clow), mmshafer@wisc.edu (M.M. Shafer).
} 


\section{Introduction}

Much environmental mercury research has focused on lowland lakes and large wetlands (Gilmour et al., 1998; Hurley et al., 1998b; Benoit et al., 2003) and coastal lowlands (Balcom et al., 2004; Hammerschmidt and Fitzgerald, 2004). These environments provide favorable conditions for $\mathrm{Hg}$ methylation and bioaccumulation in fish that people consume. Upland landscapes are also sources of mercury and sites of methylmercury production, and research in uplands has often targeted boreal systems (St. Louis et al., 1994,1996; Branfireun et al., 1996; Allan et al., 2001; Bishop et al., 1995a,b), where wetlands are a major landscape component. Boreal landscapes are rich in organic matter and anoxic conditions that favor $\mathrm{Hg}$ methylation and $\mathrm{MeHg}$ export. Research in higher-gradient, low-DOC uplands (Allan and Heyes, 1998; Scherbatskoy et al., 1998; Mast et al., 2005) has been more limited. However, scientists have increasingly recognized that these non-boreal headwater terrestrial uplands (which may contain wetlands and wetlandlike areas) both produce methylmercury and supply $\mathrm{Hg}$ that sustains $\mathrm{Hg}$ methylation in low-lying landscapes down-gradient (Munthe et al., 2007).

Much of the world's land surface is covered by forested uplands. Hg research in headwater upland landscapes is important because: (1) $\mathrm{Hg}$ deposition is enhanced at higher elevations and by forest canopy (St. Louis et al., 2001; Miller et al., 2005); (2) headwaters harbor a large pool of $\mathrm{Hg}$ with uncertain fate; and (3) the bioavailability of this $\mathrm{Hg}$ is unclear and needs to be better assessed.

Investigation of $\mathrm{Hg}$ cycling in headwater landscapes lends itself to the small watershed approach (Likens and Bormann, 1995), whereby careful mass balance in small, relatively simple ecosystems allows one to infer controlling processes. Application of the small watershed approach to investigations of $\mathrm{Hg}$ cycling remains limited (Krabbenhoft et al., 2005), but there are several examples in the literature (Krabbenhoft et al., 1995; Bishop et al, 1995a,b; Lee et al., 1998; Scherbatskoy et al., 1998; Allan and Heyes, 1998; Kolka et al., 1999; Allan et al., 2001; Schwesig and Matzner, 2001; Mast et al., 2005; Nelson et al., 2007; Harris et al., 2007). Event sampling, one of the key elements in small watershed research, is not always part of the design of these watershed studies, and has more often been applied to mesoscale or larger rivers (Hurley et al., 1995, 1998a; Babiarz et al., 1998; Balogh et al, 1997, 1998, 2005). Event sampling of flashy headwater streams is a challenging endeavor because of the unpredictability of high flows, remoteness of the sites, and the need for human presence (automated sampling of $\mathrm{Hg}$ is difficult and rare). Yet, to understand the processes and evaluate the magnitude of $\mathrm{Hg}$ dynamics in headwaters, event sampling is essential.

In this paper we use the small watershed approach with an emphasis on high-flow sampling to compare and contrast $\mathrm{THg}$ and $\mathrm{MeHg}$ cycling in five diverse sites across the USA. Unlike most upland $\mathrm{Hg}$ studies, these sites are non-boreal, low-DOC landscapes. The five watersheds comprise the USGS Water, Energy, and Biogeochemical Budgets (WEBB) research program, established in 1990 (Lins, 1994). The long-term data and biogeochemical understanding from nearly two decades of intensive research at these sites provide rich context for the interpretation of $\mathrm{Hg}$ behavior. This recent focus on $\mathrm{Hg}$ in the WEBB program builds on previous work at three of the sites: Vermont (Shanley et al., 2002; Schuster et al., 2008); Colorado (Mast et al., 2005); and Wisconsin (Krabbenhoft et al., 1995).

\section{Site descriptions}

The five sites of the WEBB program are Sleepers River, VT; Loch Vale, CO; Trout Lake, WI; Panola Mountain, GA; and Luquillo Experimental Forest, PR (Fig. 1; Table 1). Within each site, we chose a small, undisturbed catchment for our $\mathrm{Hg}$ investigations. These catchments are the same as those reported in an intercomparison of water and solute mass budgets at the five sites (Peters et al., 2006). At Sleepers River, VT, Hg was sampled at the 41-ha W-9 catchment (called Sleepers herein) (Shanley et al., 2004), a forested, glaciated, calcareous catchment with mucky histosols in riparian zones and depressions. At Loch Vale, CO, we sampled the 179-ha Andrews Creek (Andrews), an alpine catchment dominated by steep bedrock and talus slopes with $2 \%$ coniferous forest cover on lower slopes (Campbell et al., 1995). Trout Lake, WI, is a forested low-relief landscape mantled with sandy till and dotted with numerous lakes and wetlands. We sampled the 1395-ha middle site on Allequash Creek (Allequash) (Walker et al., 2003), a catchment nested within the Allequash Creek site reported in Peters et al. (2006). The 41-ha Panola Mountain, GA site (Panola) (Peters, 1989) is forested except for a 3-ha granodiorite outcrop in the headwaters. At Luquillo, PR, we sampled Rio Icacos, a 326-ha forested catchment on rapidly weathering granodiorite (White et al., 1998). All sites average $1000 \pm 300 \mathrm{~mm}$ annual precipitation, except Rio Icacos (Icacos), which averages more than $4000 \mathrm{~mm}$.

\section{Methods}

The frequency and timing of $\mathrm{Hg}$ sampling varied among the five sites (Table 2). Each site used a combination of fixed interval and high-flow event sampling to capture $\mathrm{Hg}$ dynamics in streamwater at the catchment outlet. Grab samples were taken near the centroid of flow, except occasionally from the streambank at high flow. All sites except Panola had sufficient data to compute annual budgets for at least one year.

Samples for unfiltered $\mathrm{THg}$ and $\mathrm{MeHg}$ analysis were collected in rigorously cleaned Teflon bottles and acidified with ultra-pure $6 \mathrm{~N} \mathrm{HCl}$ (Olson and DeWiild, 1999). Samples for filtered and particulate $\mathrm{THg}$ and $\mathrm{MeHg}$ analysis were collected in new polyethylene terephthalate G Copolymer (PETG) bottles and filtered within $24 \mathrm{~h}$ with pre-baked $0.7-\mu \mathrm{m}$ quartz fiber filters (QFFs) within a closed chamber using clean techniques (Lewis and Brigham, 2004). The filtrate was then acidified as above; the QFFs were stored frozen and later digested for $\mathrm{Hg}$ analysis of the particulate fraction. A small number of base flow samples $(n<10)$ were filtered during collection through an in-line filter pack assembly using 


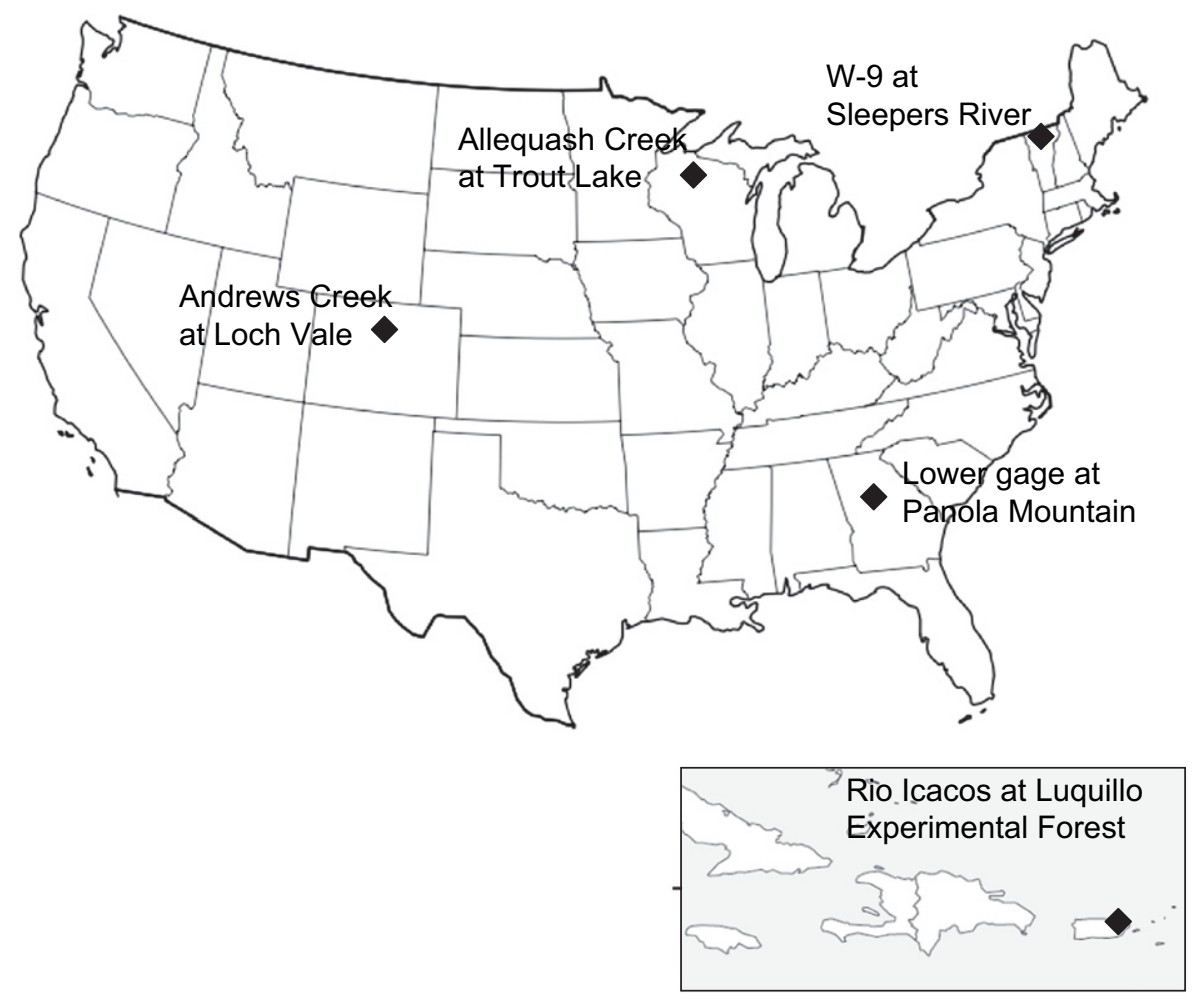

Fig. 1. Locator map of the five USGS WEBB watersheds.

a peristaltic pump with Teflon tubing. When not determined on raw samples, unfiltered $\mathrm{THg}$ and $\mathrm{MeHg}$ concentrations were calculated by summing the filtered and particulate concentrations. We prefer the term "filtered" to "dissolved" based on the finding of Babiarz et al. (2001) that much of the THg and $\mathrm{MeHg}$ passing a $0.4-\mu \mathrm{m}$ filter is colloidal. All $\mathrm{THg}$ and $\mathrm{MeHg}$ concentrations were determined by cold vapor atomic fluorescence spectrometry (CVAFS) at the USGS Mercury Laboratory in Middleton, WI (Olson and DeWild, 1999; DeWild et al., 2002).

With each Hg sample, aliquots were concurrently collected for dissolved organic carbon (DOC) in a $120-\mathrm{mL}$ amber glass bottle by on-site syringe filtration $(0.7-\mu \mathrm{m}$ glass fiber filter). For select samples, $3 \mathrm{~L}$ were filtered in-line by peristaltic

Table 1

Site characteristics of the five USGS WEBB catchments

\begin{tabular}{|c|c|c|c|c|c|}
\hline & \multicolumn{5}{|l|}{ USGS WEBB site } \\
\hline & Loch Vale, CO & Luquillo Forest, PR & Trout Lake, WI & Panola Mountain, GA & Sleepers River, VT \\
\hline Watershed & Andrews Creek & Rio Icacos & Allequash Creek & Lower Gage & W-9 \\
\hline Ecosystem type & $\begin{array}{l}\text { Alpine tundra/boreal } \\
\text { forest }\end{array}$ & Subtropical wet forest & $\begin{array}{l}\text { Northern lakes } \\
\text { and forests }\end{array}$ & Southern hardwood forest & $\begin{array}{l}\text { Northern hardwood } \\
\text { forest }\end{array}$ \\
\hline Catchment area (ha) & 179 & 326 & 1395 & 41 & 41 \\
\hline Outlet elevation (m) & 3215 & 616 & 494 & 225 & 524 \\
\hline Highest elevation (m) & 3850 & 844 & 555 & 270 & 679 \\
\hline Mean slope $(\%)$ & 66 & 21 & 0.28 & 18 & 22 \\
\hline Climate type & Cold continental & Humid tropical & Humid continental & Humid continental/subtropical & Humid continental \\
\hline $\begin{array}{l}\text { Mean annual } \\
\text { temperature }\left({ }^{\circ} \mathrm{C}\right)\end{array}$ & 0 & 21 & 4.5 & 16 & 4.5 \\
\hline $\begin{array}{l}\text { Mean annual } \\
\text { precipitation }(\mathrm{mm})\end{array}$ & 1230 & 4210 & 760 & 1300 & 1320 \\
\hline $\begin{array}{l}\text { Mean annual } \\
\text { runoff }(\mathrm{mm})\end{array}$ & 970 & 3690 & 300 & 490 & 670 \\
\hline Bedrock & Biotite schist & Quartz diorite & Amphibolite & Granodiorite/amphibolite & Phyllite/granulite \\
\hline Surficial geology & Thin soil/talus & Colluvium & Glacial drift & Colluvium & Silty calcareous till \\
\hline Soil type & Spodosols & Inceptisols/ultisols & Spodosols & Inceptisols/ultisols & Inceptisols/spodosols \\
\hline Forest cover (\%) & 2 & 99 & 84 & 91 & 100 \\
\hline $\begin{array}{l}\text { Wetland and } \\
\text { lake cover }(\%)\end{array}$ & 1 & 2 to 5 & 16 & 1 & 4 \\
\hline Water type & $\mathrm{Ca}-\mathrm{Mg}$ sulfate nitrate & $\mathrm{Na}-\mathrm{Ca}-\mathrm{Cl}$-bicarbonate & $\mathrm{Ca}-\mathrm{Mg}$ bicarbonate & Na-bicarbonate-sulfate & Ca-bicarbonate-sulfate \\
\hline
\end{tabular}


Table 2

Summary of sample quantities and concentration model regressions for stream flux calculations

\begin{tabular}{|c|c|c|c|c|c|c|c|c|c|c|c|c|c|c|c|c|c|c|c|}
\hline & \multirow[t]{2}{*}{ Years } & \multicolumn{3}{|c|}{ Filtered $\mathrm{THg}$} & \multicolumn{3}{|c|}{ Filtered $\mathrm{MeHg}$} & \multicolumn{3}{|c|}{ Particulate $\mathrm{THg}$} & \multicolumn{3}{|c|}{ Particulate $\mathrm{MeHg}$} & \multicolumn{3}{|c|}{ Unfiltered $\mathrm{THg}$} & \multicolumn{3}{|c|}{ Unfiltered $\mathrm{MeHg}$} \\
\hline & & $n$ & $r^{2}$ & Model & $n$ & $r^{2}$ & Model & $n$ & $r^{2}$ & Model & $n$ & $r^{2}$ & Model & $n$ & $r^{2}$ & Model & $n$ & $r^{2}$ & Model \\
\hline Sleepers & 4 & 19 & 0.26 & Q & & $<\mathrm{DL}$ & & & & & & & & 54 & 0.37 & $\mathrm{Q}$ & 53 & 0.34 & Q \\
\hline Andrews & 3 & & & & & & & & Negligible & & & Negligible & & 85 & & HB & & $<\mathrm{DL}$ & \\
\hline Allequash & 2 & 34 & 0.35 & $\mathrm{Q}, \mathrm{S}$ & 35 & 0.15 & S & 28 & 0.17 & $\mathrm{~S}$ & 22 & & $\mathrm{HB}$ & & & & & & \\
\hline Panola & 0 & 6 & & & 6 & & & & & & & & & 11 & & & 9 & & \\
\hline
\end{tabular}

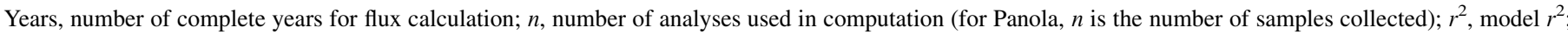

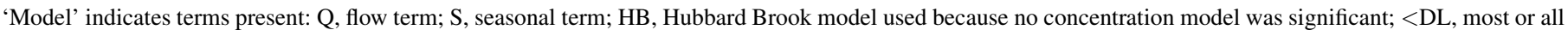
concentrations below detection limit.

pump and cartridge glass fiber filter into glass amber bottles for analysis of carbon fractions (Aiken et al., 1992). DOC and $\mathrm{C}$ fractions were determined at the USGS laboratory in Boulder, CO. Additional aliquots were collected for total suspended solids (TSS) and particulate organic carbon (POC) analysis and filtered with separate glass fiber filters for gravimetric determination at the Chesapeake Biological Laboratory in Solomons, MD.

At three sites, THg input flux in precipitation was measured near (Allequash, Andrews) or a few kilometers away (Icacos) from the stream site. Allequash used site WI36 of the Mercury Deposition Network (MDN). The Icacos site is not in the MDN but is operated under MDN protocols, using the same laboratory for analysis (Frontier Geosciences, Seattle, WA). Deposition flux at Icacos was scaled to the higher precipitation amount at the higher-elevation watershed. At Andrews, weekly bulk deposition was sampled during the non-snow period, and an April snowpack sample represented $\mathrm{Hg}$ deposition for the November-April snow accumulation period, recognizing that some revolatilization of $\mathrm{Hg}$ may have occurred (Mast et al., 2005). At Sleepers, both wet and dry $\mathrm{Hg}$ deposition were estimated from the regional model of Miller et al. (2005), which utilizes regional wet $\mathrm{Hg}$ deposition data and models dry deposition considering $\mathrm{Hg}$ sources, elevation, and land cover type. Hg dry deposition at the other three sites was estimated assuming that dry deposition is two times wet deposition on the forested parts of the watershed (St. Louis et al., 2001). Hg deposition was not estimated at Panola as no mass balance was computed.

Continuous stream stage was recorded at all sites at onehour or finer increments, and converted to discharge through empirical ratings. $\mathrm{THg}$ and $\mathrm{MeHg}$ output fluxes in streamwater were computed by the composite method (Aulenbach and Hooper, 2006), which builds a concentration model based on stream discharge, and sine/cosine terms that simulate seasonality. Modeled concentrations were adjusted to match actual sample concentrations, and adjusted between samples by the model residuals linearly interpolated through time between successive samples. Occasionally, e.g. after a storm, the concentration was forced to the modeled value to avoid carrying a high residual through a long period without samples. Finally, adjusted model $\mathrm{THg}$ and $\mathrm{MeHg}$ concentrations were multiplied by water flux to compute their respective fluxes.
Streamwater fluxes of unfiltered (or particulate, if measured) and filtered $\mathrm{THg}$ and $\mathrm{MeHg}$ were calculated independently at each site to the extent possible (Table 2). Icacos had strong concentration-discharge relations with no seasonal component for both $\mathrm{THg}$ and $\mathrm{MeHg}$. At Sleepers, concentration-discharge relations were much weaker but still significant ( $p<0.0001$ except for filtered THg, $p<0.02$ ). At Allequash, only filtered $\mathrm{THg}$ had a significant relation with flow, but filtered $\mathrm{THg}$, filtered $\mathrm{MeHg}$, and particulate $\mathrm{THg}$ had seasonal components, resulting in significant concentration models $(p<0.0005)$ for these three fractions. Fluxes computed from these three models were very similar to those computed using the period-weighted approach (also known as the Hubbard Brook approach, where a sample concentration is assigned to all flow between the midpoints of successive samples (Likens and Bormann, 1995)). Due to lack of significant models, we applied the Hubbard Brook approach for particulate $\mathrm{MeHg}$ at Allequash and for unfiltered $\mathrm{THg}$ at Andrews.

\section{Results and discussion}

\subsection{Hg concentration dynamics}

The distribution of samples on the flow duration curves indicates that high flows were effectively captured at all sites (Fig. 2). Low-flow regimes were also adequately represented. The very highest flows $(<5 \%$ exceedance) were missed at Andrews, but high flow sampling at this site is the least critical because of the low slope on the high-flow end of the flow duration curve.

The five sites can be arranged in two groups with contrasting THg dynamics (Fig. 3). One group included Sleepers, Icacos, and Panola, and had high THg concentrations that ranged above $50 \mathrm{ng} \mathrm{L}^{-1}$, strongly dominated by particulate $\mathrm{THg}$ (unfiltered $\mathrm{THg}$ minus filtered $\mathrm{THg}$ ). The higher median and range at Icacos was influenced in part by a relatively greater emphasis on high flow sampling at that site (Fig. 2). The second group included Andrews and Allequash, and had lower THg concentrations dominated by the filtered fraction. The filtered $\mathrm{THg}$ fraction accounted for nearly all of the $\mathrm{THg}$ at Andrews and most of the THg at Allequash.

Filtered $\mathrm{THg}$ concentrations were more uniform than unfiltered $\mathrm{THg}$ concentrations across the five sites; median filtered 


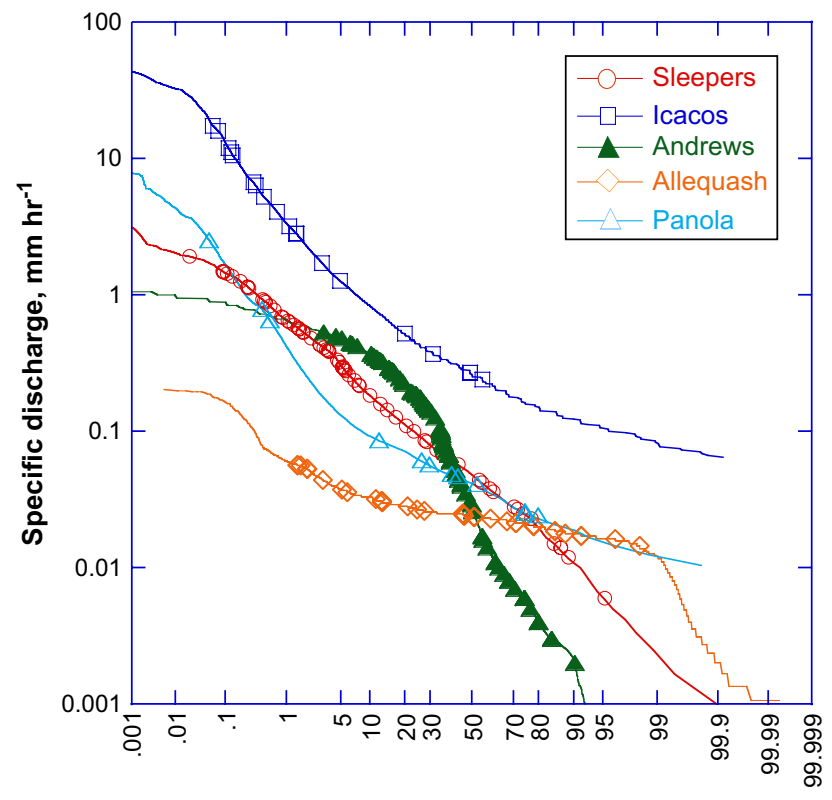

Percent of time flow exceeded

Fig. 2. Mercury samples plotted on flow duration curves for the five WEBB watersheds.

THg concentrations ranged from $1.0 \mathrm{ng} \mathrm{L}^{-1}$ at Allequash and Andrews to $2.0 \mathrm{ng} \mathrm{L}^{-1}$ at Sleepers and Icacos (Fig. 3). Panola had a median filtered THg concentration of $2.4 \mathrm{ng} \mathrm{L}^{-1}$, but this value was based on only 6 storm samples. Sleepers and Icacos each had maximum filtered $\mathrm{THg}$ concentrations near $5 \mathrm{ng} \mathrm{L}^{-1}$.

The maximum concentrations for unfiltered $\mathrm{THg}$ of $112 \mathrm{ng}$ $\mathrm{L}^{-1}$ at Icacos and $94 \mathrm{ng} \mathrm{L}^{-1}$ at Sleepers are among the highest values reported in the literature for pristine sites. Only two storms were sampled at Panola, and the maximum of $55 \mathrm{ng}$ $\mathrm{L}^{-1}$ occurred during a relatively small storm, suggesting a potential for even higher concentrations at this site. Scherbatskoy et al. (1998) reported an unfiltered THg concentration of $80 \mathrm{ng} \mathrm{L}^{-1}$ during snowmelt in a small forested Vermont stream. Schwesig and Matzner (2001) reported two values greater than $100 \mathrm{ng} \mathrm{L}^{-1}$ in filtered samples during a year of biweekly sampling in a German catchment. In less pristine environments, Balogh et al. (2005) reported maximum concentrations near $70 \mathrm{ng} \mathrm{L}^{-1}$ in agricultural Minnesota rivers and Hurley et al. (1998a) reported a maximum THg concentration of $182 \mathrm{ng} \mathrm{L}^{-1}$ in an industrially impacted Wisconsin river.

The range of $\mathrm{MeHg}$ was somewhat more uniform than $\mathrm{THg}$ among sites, with median concentrations for both filtered and unfiltered $\mathrm{MeHg}$ fractions ranging from below detection (0.04 $\mathrm{ng} \mathrm{L}^{-1}$ ) to $0.2 \mathrm{ng} \mathrm{L}^{-1}$ (Fig. 3). Unfiltered $\mathrm{MeHg}$ values ranged up to $1.1 \mathrm{ng} \mathrm{L}^{-1}$ at Allequash and $2.6 \mathrm{ng} \mathrm{L}^{-1}$ at Sleepers. As with $\mathrm{THg}, \mathrm{MeHg}$ at Sleepers, Icacos, and Panola was generally greater in the particulate fraction. Only Allequash had $\mathrm{MeHg}$ consistently above detection in both fractions, and here most of the $\mathrm{MeHg}$ was in the filtered fraction. Andrews consistently had MeHg below detection. Except in some wetland systems, $\mathrm{MeHg}$ concentrations reported for forest streams are generally $<1 \mathrm{ng} \mathrm{L}^{-1}$ (Branfireun et al., 1996; Allan and Heyes, 1998; Munthe and Hultberg, 2004; Nelson et al., 2007); high $\mathrm{MeHg}$ concentrations would not have been detected without high-flow sampling.

\subsection{Episodic transport}

A marked increase in $\mathrm{THg}$ and $\mathrm{MeHg}$ concentrations during high-flow events (Fig. 4) was a key feature at most of these sites. At the high-THg sites (Sleepers, Icacos, Panola), this increase was most prevalent for the unfiltered $\mathrm{THg}$ and $\mathrm{MeHg}$ fractions with a more moderate increase in the filtered fractions. THg concentrations at Andrews did not rise as high as those at these other three sites but increased sharply relative
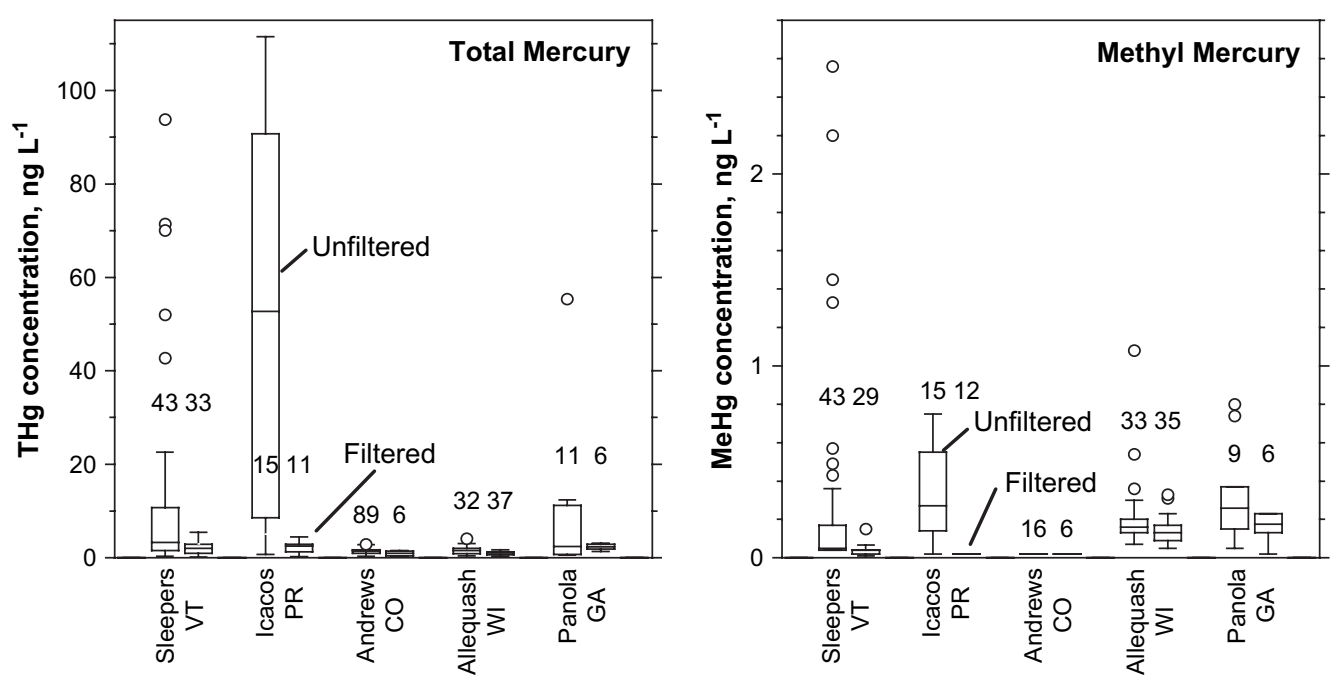

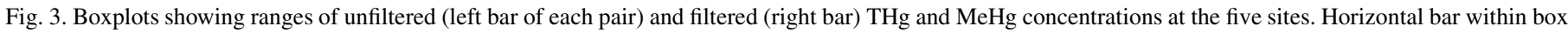

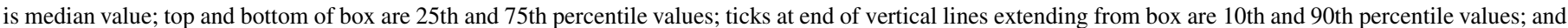
circles represent individual values at the extremes of the range. Numbers on plot show number of samples for each boxplot. 

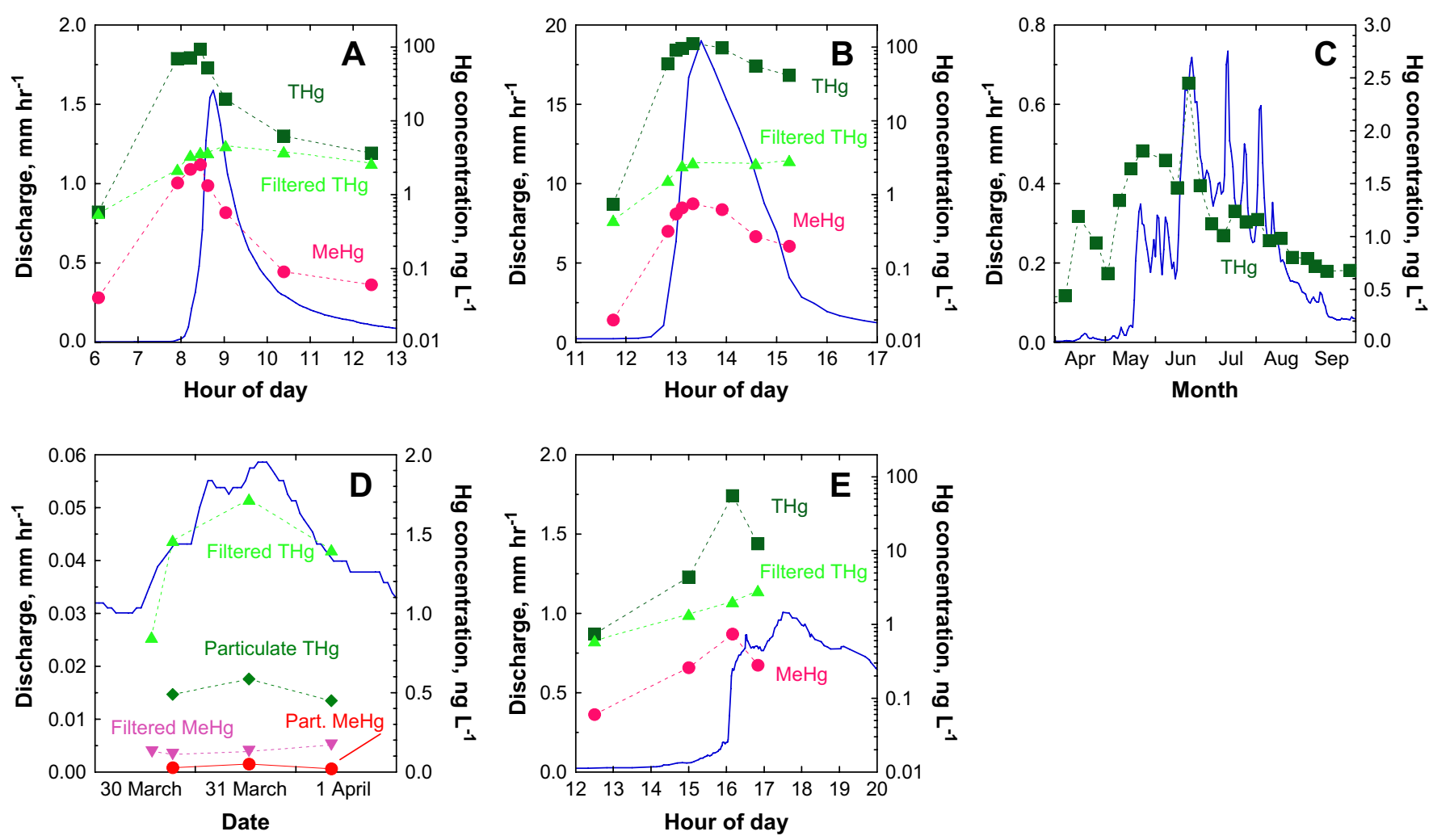

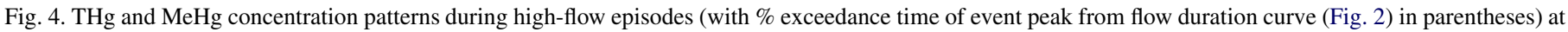

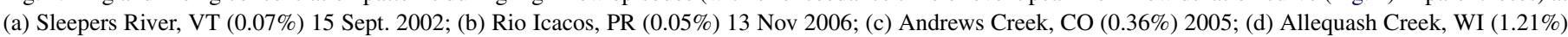
2006; and (e) Panola Mt., GA (0.23\%) 15 Nov 2006. Unless otherwise indicated, concentrations are for unfiltered samples.

to base flow periods. THg and $\mathrm{MeHg}$ concentrations at the groundwater-dominated Allequash system were least sensitive of the five sites to changes in flow, though a few elevated values occurred during snowmelt. Sleepers, Andrews, and Panola showed hysteresis, whereby $\mathrm{THg}$ and $\mathrm{MeHg}$ had higher concentrations on the rising limb of the hydrograph relative to the same discharge on the falling limb. Hysteresis was minimal at Icacos.

$\mathrm{THg}$ and $\mathrm{MeHg}$ concentrations generally increased in parallel during events (Fig. 4), suggesting common sources for the two species. At Sleepers we have inferred that near-stream or in-stream particulate organic matter, mobilized during storms (Hall and St. Louis, 2004), is the common source for THg and MeHg (Schuster et al., 2008). Mobilization of particulate organic matter is also a plausible mechanism at Panola, where in-stream sediment is high in organic matter, and at Icacos, where bed sediment and suspended sediment are low in organic matter but there is a high correlation of $\mathrm{THg}$ and POC (see below).

Episodic transport of THg driven by large concurrent increases in THg concentrations and streamflow has been well documented (Hurley et al., 1998a; Babiarz et al., 1998; Balogh et al., 2005; Scherbatskoy et al., 1998). Episodic transport of $\mathrm{MeHg}$ has been less commonly observed but does occur (Branfireun et al., 1996; Babiarz et al., 1998). Our finding of parallel patterns in $\mathrm{THg}$ and $\mathrm{MeHg}$ concentrations in the current study contrasts with most published studies that show either scattered or even divergent patterns. Allan et al. (2001), at a small stream in the Canadian Precambrian Shield, found that $\mathrm{THg}$ decreased with flow after an initial flush at the start of an event, but that $\mathrm{MeHg}$ had a varying response to flow. Allan and Heyes (1998) likewise found that THg and $\mathrm{MeHg}$ were decoupled during storm events at Coweeta, NC; $\mathrm{THg}$ increased with flow while $\mathrm{MeHg}$ changed little. Schwesig and Matzner (2001) found $\mathrm{THg}$ and $\mathrm{MeHg}$ were decoupled in a German catchment. In Swedish catchments, Bishop et al. (1995a,b) found divergent patterns; THg increased with flow while $\mathrm{MeHg}$ decreased. These authors identified organic-rich soils as the source of both $\mathrm{THg}$ and $\mathrm{MeHg}$, but attributed the decline in $\mathrm{MeHg}$ to a low net methylation rate relative to the hydrologic flushing rate.

\subsection{Mercury fluxes}

Annual streamwater THg fluxes ranged over two orders of magnitude among the four watersheds quantified (Table 3; Fig. 5), from an average $0.25 \mu \mathrm{g} \mathrm{m}^{-2}$ year $^{-1}$ at Allequash to $54.4 \mu \mathrm{g} \mathrm{m}^{-2}$ year $^{-1}$ at Icacos. THg fluxes at Sleepers $\left(3.26 \mu \mathrm{g} \mathrm{m}^{-2}\right.$ year $\left.^{-1}\right)$ and Andrews $\left(1.55 \mu \mathrm{g} \mathrm{m}^{-2}\right.$ year $\left.^{-1}\right)$ were intermediate, about one order of magnitude from each extreme. Most streamwater THg fluxes reported in the literature for pristine forested catchments are similar to our mid- 
Table 3

Water and mercury input and output fluxes at four of the WEBB sites

\begin{tabular}{|c|c|c|c|c|c|c|c|c|c|c|c|}
\hline \multirow[t]{3}{*}{ Site } & \multirow[t]{3}{*}{ Full year end date } & \multicolumn{2}{|c|}{ Water $(\mathrm{mm})$} & \multicolumn{8}{|c|}{ Mercury $\left(\mu \mathrm{g} \mathrm{m}^{-2}\right.$ year $\left.^{-1}\right)$} \\
\hline & & \multirow[t]{2}{*}{ In } & \multirow[t]{2}{*}{ Out } & \multicolumn{2}{|c|}{ Atmospheric input } & \multicolumn{6}{|c|}{ Stream output ${ }^{\mathrm{c}}$} \\
\hline & & & & $\begin{array}{l}\text { Wet } \\
\mathrm{THg}^{\mathrm{a}}\end{array}$ & $\begin{array}{l}\text { Dry } \\
\text { THg }^{b}\end{array}$ & $\begin{array}{l}\text { Filtered } \\
\mathrm{THg}\end{array}$ & $\begin{array}{l}\text { Filtered } \\
\mathrm{MeHg}\end{array}$ & $\begin{array}{l}\text { Particulate } \\
\text { THg }\end{array}$ & $\begin{array}{l}\text { Particulate } \\
\mathrm{MeHg}\end{array}$ & $\begin{array}{l}\text { Unfiltered } \\
\text { THg }\end{array}$ & $\begin{array}{l}\text { Unfiltered } \\
\mathrm{MeHg}\end{array}$ \\
\hline \multirow[t]{5}{*}{ Sleepers, VT } & $9 / 30 / 2002$ & 1373 & 768 & & & 1.17 & & & & 3.03 & 0.058 \\
\hline & 9/30/2003 & 1174 & 638 & & & 1.19 & & & & 2.43 & 0.039 \\
\hline & $9 / 30 / 2004$ & 1432 & 941 & & & 1.65 & & & & 4.67 & 0.077 \\
\hline & 9/30/2005 & 1236 & 699 & & & 0.74 & & & & 2.92 & 0.049 \\
\hline & Average & 1304 & 761 & 8.2 & 16.9 & 1.19 & $0.0152^{\mathrm{d}}$ & & & 3.26 & 0.056 \\
\hline Icacos, PR & $12 / 31 / 2006$ & 4362 & 3692 & 39.7 & 79.4 & 3.48 & $0.076^{\mathrm{d}}$ & & & 54.38 & 0.370 \\
\hline \multirow[t]{4}{*}{ Andrews, $\mathrm{CO}$} & $9 / 30 / 2003$ & 1270 & 1110 & 9.5 & 0.4 & & & & & 1.78 & \\
\hline & $9 / 30 / 2004$ & 1210 & 790 & 8.4 & 0.3 & & & & & 1.50 & \\
\hline & $9 / 30 / 2005$ & 1170 & 1010 & 8.9 & 0.4 & & & & & 1.38 & \\
\hline & Average & 1217 & 970 & 8.9 & 0.4 & & & & & 1.55 & $0.019^{\mathrm{d}}$ \\
\hline \multirow[t]{3}{*}{ Allequash, WI } & $3 / 31 / 2005$ & 756 & 203 & 7.2 & 12.1 & 0.14 & 0.022 & 0.064 & 0.006 & 0.20 & 0.028 \\
\hline & $3 / 31 / 2006$ & 783 & 221 & 7.5 & 12.6 & 0.20 & 0.039 & 0.093 & 0.006 & 0.30 & 0.046 \\
\hline & Average & 770 & 212 & 7.4 & 12.3 & 0.17 & 0.031 & 0.078 & 0.006 & 0.25 & 0.037 \\
\hline
\end{tabular}

${ }^{a}$ Wet deposition Hg input: Sleepers, annual average from regional model (Miller et al., 2005); Allequash from MDN station WI36; Icacos from lower elevation site using MDN protocols; wet deposition of $26.4 \mu \mathrm{g} \mathrm{m}^{-2}$ with $2900 \mathrm{~mm}$ precipitation scaled to $4362 \mathrm{~mm}$ precipitation at watershed; Andrews from snowpack (winter) or bulk collector (summer).

${ }^{\mathrm{b}}$ Dry deposition Hg input: Sleepers, annual average from regional model (Miller et al., 2005); other sites assumed that forested areas had dry deposition two times wet deposition.

c Output assumed to be dissolved at Andrews (negligible suspended sediment); a subset of samples was filtered at Sleepers and Icacos; unfiltered values used in flux calculations were a combination of directly measured values and computed values (filtered + particulate). All samples were filtered at Allequash, unfiltered fluxes were computed as sum of filtered and particulate fluxes. Except at Allequash, filtered MeHg (unfiltered at Andrews) was always or nearly always below detection, so filtered $\mathrm{MeHg}$ flux (Unfiltered $\mathrm{MeHg}$ flux at Andrews) was calculated assuming concentration was always one half detection limit. These estimated fluxes were not added to the corresponding unfiltered fluxes.

${ }^{\mathrm{d}}$ Estimated assuming $\mathrm{MeHg}$ concentration of $0.02 \mathrm{ng} \mathrm{L}^{-1}$, one-half the detection limit.

range values, including (all values in $\mu \mathrm{g} \mathrm{m}^{-2}$ year $^{-1}$ ) 2.3 at Gårdsjön, Sweden (Munthe and Hultberg, 2004); 1.3 at Svartberget, Sweden and 3.2 at Paroninkorpi, Finland (Lee et al., 1998); 1.2-2.1 in Ontario (St. Louis et al., 1994); 0.7-2.8

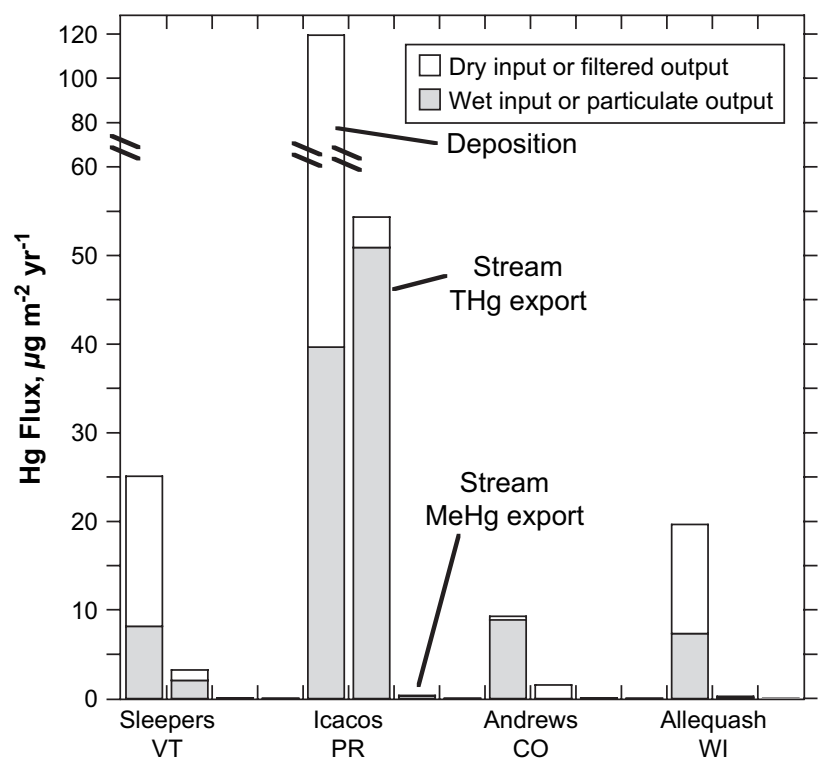

Fig. 5. Mercury fluxes at the four sites quantified for the periods indicated in Table 3. Inputs are measured wet deposition and estimated dry deposition as described in text. Output stream flux calculations for $\mathrm{THg}$ and $\mathrm{MeHg}$ described in text; apportioned to filtered and particulate load where possible. Fluxes too small to discern are included in Table 3. in Minnesota (Kolka et al., 1999); and 0.4-1.3 at Acadia National Park, Maine (Nelson et al., 2007). Schwesig and Matzner (2001) reported THg export of $15.9 \mu \mathrm{g} \mathrm{m}^{-2}$ year $^{-1}$ in the forested Lehstenbach catchment in industrialized central Europe.

At Icacos, more than 93\% of the THg export was in the particulate fraction, compared to $63 \%$ at Sleepers, $31 \%$ at Allequash, and $\sim 0 \%$ at Andrews. This order of decreasing particulate $\mathrm{THg}$ reflects the decreasing importance of episodes to Hg export, except at Andrews, where events dominated THg export but mostly as filtered $\mathrm{Hg}$ because the stream had very little suspended sediment (Mast et al., 2005).

Despite the two order of magnitude difference in $\mathrm{THg}$ flux, Allequash and Icacos had only a one order of magnitude difference in $\mathrm{MeHg}$ flux $\left(0.037\right.$ vs. $0.37 \mu \mathrm{g} \mathrm{m}^{-2}$ year $^{-1}$, respectively). Sleepers MeHg export $\left(0.056 \mu \mathrm{g} \mathrm{m}^{-2}\right.$ year $\left.^{-1}\right)$ was similar to that at Allequash, whereas Andrews had no detectable MeHg. Published values of $\mathrm{MeHg}$ fluxes are uncommon, but the Sleepers and Allequash $\mathrm{MeHg}$ fluxes fall within the range of those reported. Lee et al. (1998) reported $0.03-0.16 \mu \mathrm{g} \mathrm{m}^{-2}$ year $^{-1}$ for four Swedish and Finnish catchments. Schwesig and Matzner (2001) reported $0.089 \mu \mathrm{g} \mathrm{m}^{-2}$ year $^{-1}$ for filtered MeHg in a German catchment. Balogh et al. (2005) calculated $0.03-0.09 \mu \mathrm{g} \mathrm{m} \mathrm{m}^{-2}$ year $^{-1} \mathrm{MeHg}$ export for five Minnesota rivers. At Allequash, about $80 \%$ of the $\mathrm{MeHg}$ export was in the filtered fraction, whereas nearly all the $\mathrm{MeHg}$ export at Sleepers and Icacos was particulate. 
These MeHg fluxes in streamwater could potentially be accounted for by wet and dry deposition of $\mathrm{MeHg}$ (St. Louis et al., 2001; Hall et al., 2005), with the possible exception of Icacos (where measurements are lacking). However, just as THg newly deposited to uplands is sequestered by soils and vegetation and only slowly (over years) released to surface waters (Harris et al., 2007), atmospheric $\mathrm{MeHg}$ inputs to the forest floor are unlikely to enter streamwater rapidly and without transformation. Rather, there is ample evidence that watershed processes exert a stronger control than atmospheric deposition on $\mathrm{MeHg}$ concentrations in water and accumulation in fish (Driscoll et al., 2007; Evers et al., 2007; Munthe et al., 2007).

The high THg flux at Icacos is due in part to high wet $\mathrm{Hg}$ deposition, which is the highest measured in the USA (Shanley et al., 2006), and high stream runoff, which averages $3610 \mathrm{~mm} \mathrm{year}^{-1}$ (Peters et al., 2006). However, the stream THg flux $\left(55.4 \mu \mathrm{g} \mathrm{m}^{-2}\right.$ year $\left.^{-1}\right)$ exceeded the $\mathrm{Hg}$ input in precipitation (estimated as $39.7 \mu \mathrm{g} \mathrm{m}^{-2}$ year $^{-1}$ by scaling up from the $26.4 \mu \mathrm{g} \mathrm{m}^{-2}$ year $^{-1}$ at the deposition station by the difference in precipitation (4362 vs. $2900 \mathrm{~mm}$ )). Dry deposition and possibly cloudwater deposition of $\mathrm{Hg}$ likely shift the balance to a net $\mathrm{Hg}$ retention (subject to unmeasured volatilization losses), but compared to most other sites landscape retention is minimal at Icacos. One explanation could be frequent landslides (Larsen and Torres Sánchez, 1998); disturbance mobilizes $\mathrm{THg}$ and $\mathrm{MeHg}$ (Porvari et al., 2003; Munthe and Hultberg, 2004). The apparent limited Hg retention may also be an artifact of a geologic source or of $\mathrm{Hg}$ used in placer gold mining in this area in the late 19th and early 20th centuries (Wardsworth, 1949; Cardona, 1984).

$\mathrm{THg}$ export in excess of wet $\mathrm{Hg}$ input is extremely rare; ignoring possible volatilization losses, watersheds typically retain 70-95\% of $\mathrm{Hg}$ inputs in precipitation (Krabbenhoft et al., 2005; Grigal, 2002; Quémerais et al., 1999; Scherbatskoy et al., 1998; Allan and Heyes, 1998; Mast et al., 2005). Lee et al. (1998) reported lower retention (37\%) at a low-lying watershed in southern Finland, and attributed it to the dominance of shallow flow paths through organic-rich soils.

Sleepers retained $60 \%$ of $\mathrm{THg}$ in wet deposition (Fig. 5). Wet $\mathrm{THg}$ deposition was derived from the model of Miller et al. (2005), based on regional measurements. This retention percentage is considerably lower than is typical, and may reflect the focus on event sampling (Fig. 2), whereby we captured a component of export that may often be overlooked. Miller et al. (2005) also modeled dry deposition, considering speciation, elevation, and land cover type. There is increasing recognition that dry deposition may exceed wet deposition in forested landscapes (Kolka et al., 1999; St. Louis et al., 2001; Miller et al., 2005). The modeled dry deposition at Sleepers, including uptake of $\mathrm{Hg}^{0}$ by foliage, was $16.9 \mu \mathrm{g} \mathrm{m}^{-2}$ year ${ }^{-1}$ (E. Miller, personal communication). Factoring in dry deposition, watershed THg retention at Sleepers was $87 \%$ of atmospheric input.

At Andrews, watershed $\mathrm{Hg}$ retention was $83 \%$ of bulk $\mathrm{Hg}$ input, in close agreement with earlier estimates for this site (Mast et al., 2005). The bulk Hg input measured at Andrews is likely a reasonable approximation of total $\mathrm{Hg}$ deposition, except for a small amount of additional dry input in the $2 \%$ of the basin that is forested (Table 3; Mast et al., 2005). Most snowmelt and rainfall in the Andrews basin flows through shallow subsurface flow paths to the alpine stream. These flow paths regulate the export of other chemical constituents (Campbell et al., 1995; Clow et al., 2003), and likely explain why such a high percentage of the $\mathrm{Hg}$ input is retained, despite thin, patchy soil cover.

At Allequash, $96.6 \%$ of wet $\mathrm{Hg}$ input was retained in the basin. Accounting for estimated dry deposition (Table 3), $\mathrm{Hg}$ retention increased to $98.7 \%$. About two-thirds of stream THg export was in the filtered fraction. Dominance by the filtered fraction is typical for low-gradient landscapes, although Kolka et al. (2001) found 70\% of THg exported in association with POC in a Minnesota bog watershed. Stream THg export at Allequash was about one half that reported from the same watershed in the early 1990s based on analysis of unfiltered samples (Krabbenhoft et al., 1995). The lower export (greater retention) in the present study may be a consequence of dry conditions; runoff at Allequash averaged $210 \mathrm{~mm}$ per year compared to $310 \mathrm{~mm}$ per year in the previous study.

$\mathrm{MeHg}$ flux made up a much higher proportion (14.8\%) of the THg flux at Allequash than at the other sites. Despite the lower percent $\mathrm{MeHg}$ flux at Sleepers (1.7\%) and Icacos $(0.7 \%)$, the larger THg fluxes at these sites resulted in slightly more (Sleepers) and an order of magnitude more (Icacos) $\mathrm{MeHg}$ export compared to Allequash. MeHg export at Icacos and Sleepers, however, was dominated by the particulate fraction (filtered $\mathrm{MeHg}$ was generally below detection). Particulate $\mathrm{MeHg}$ may be less readily assimilated by aquatic biota, thus low-relief systems like Allequash, despite retaining most of the incoming $\mathrm{Hg}$, may show the most adverse biological effects because of greater $\mathrm{MeHg}$ availability.

The export of MeHg from these catchments suggests that upland landscapes have zones and conditions conducive to $\mathrm{Hg}$ methylation, and may serve as an entry point for $\mathrm{MeHg}$ in the aquatic food web, and/or export MeHg to downgradient ecosystems where it may be taken up. Moreover, the high THg fluxes from these uplands suggest that they are an important source of $\mathrm{THg}$ for methylation in lowland streams, wetlands, and lakes (Allan et al., 2001; Munthe et al., 2007). Even if exported in the particulate fraction, THg is available for methylation in downstream receiving waters if desorbed or upon decomposition of the binding organic matter (Hurley et al., 1998a), though questions remain about the bioavailability of this particulate THg (Munthe et al., 2007).

\subsection{Controls on THg concentration}

At Sleepers, Icacos, and Panola, THg was dominated by the particulate fraction, and the THg-POC relation for Sleepers and Icacos (no POC data were available for Panola) had a strikingly similar slope (Fig. 6), despite their large physical and climatic differences. Allequash had a lower slope. At Andrews, there was little particulate matter so the unfiltered $\mathrm{Hg}$ fraction was assumed equal to filtered $\mathrm{Hg}$. The lack of sediment 


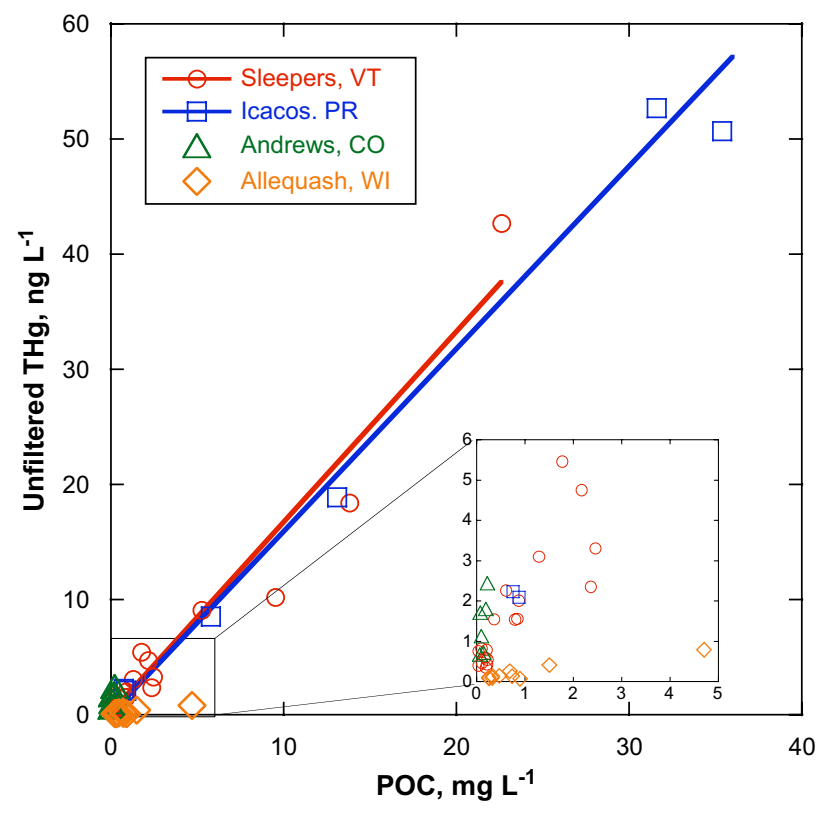

Fig. 6. Unfiltered THg vs. POC at the five WEBB watersheds.

transport at Andrews is one explanation for the low overall THg export.

A similar strong positive relation was evident for filtered THg and DOC (Fig. 7). Sleepers, Icacos, and Allequash had similar slopes, while Andrews had a much steeper slope. The ratio of filtered $\mathrm{Hg}$ to DOC in $\mathrm{ng} \mathrm{Hg} / \mathrm{mg}$ DOC was $0.36 \pm 0.10(n=26)$ at Sleepers; $0.37 \pm 0.16(n=4)$ at Icacos; $0.24 \pm 0.08(n=26)$ at Allequash; and $2.94 \pm 1.82$ $(n=86)$ at Andrews. These ratios are all higher than the $\sim 0.2 \mathrm{ng} \mathrm{Hg} / \mathrm{mg}$ DOC average from the literature reported by Grigal (2002), suggesting that in these low-DOC systems, more $\mathrm{Hg}$ is mobilized per unit of DOC. Despite this greater than average "efficiency" of $\mathrm{Hg}$ mobilization by DOC, however, mobilization by particles still dominated overwhelmingly

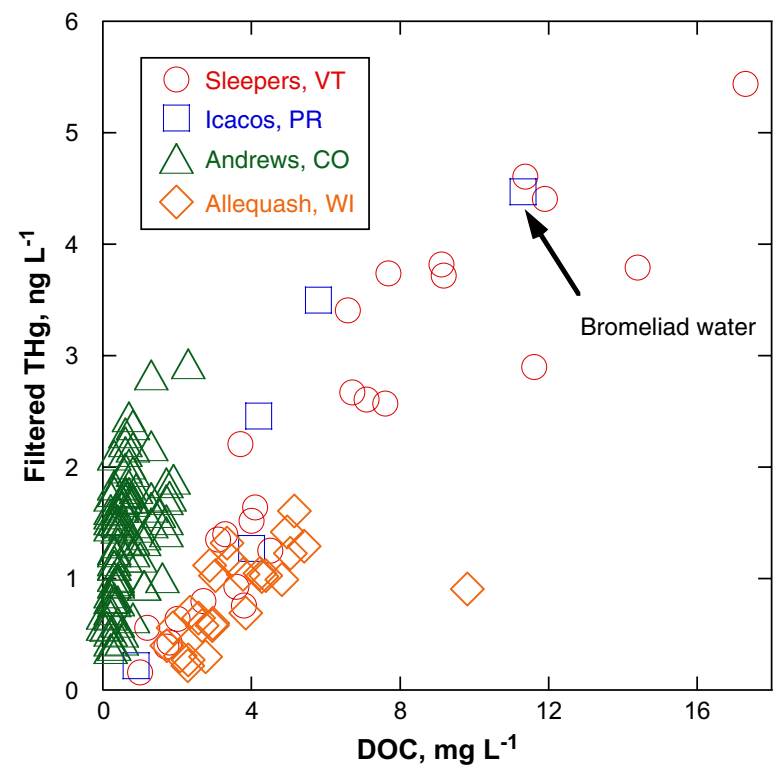

Fig. 7. Filtered THg vs. DOC at the five WEBB watersheds. at Sleepers, Icacos, and Panola; note that the scale on the filtered THg plot is an order of magnitude lower (Fig. 7).

The hydrophobic acid fraction of the DOC (HPOA) is an even stronger predictor of filtered $\mathrm{Hg}$ than bulk DOC, as demonstrated for Sleepers (Fig. 8). HPOA comprises about $50 \%$ of the DOC at all sites, and is known to contain the reduced $\mathrm{S}$ sites that bind $\mathrm{Hg}$ (Haitzer et al., 2002; Ravichandran, 2004). The narrow range of \%HPOA in DOC resulted in a strong relation between filtered $\mathrm{THg}$ and total DOC, even though HPOA was probably driving this relation.

\subsection{Controls on MeHg concentration}

As for $\mathrm{THg}, \mathrm{MeHg}$ was dominated by the particulate fraction at Sleepers, Icacos, and Panola. Unfiltered $\mathrm{MeHg}$ was strongly correlated with POC at Sleepers $\left(r^{2}=0.93\right.$, $p<0.0001, n=30)$ and at Icacos $\left(r^{2}=0.83, p=0.0004\right.$, $n=9$ ) (no data were available from Panola). While the two sites had similar slopes for the unfiltered THg-POC relation, the slope of the unfiltered $\mathrm{MeHg}$-POC relation was more than 2 times greater at Sleepers than at Icacos. Filtered $\mathrm{MeHg}$ dominated at Allequash, the only site where it was consistently above the method detection limit. In contrast to the strong unfiltered $\mathrm{MeHg}$-POC relation, filtered $\mathrm{MeHg}$ did not correlate with DOC.

Each of the five WEBB catchments had a characteristic streamwater $\mathrm{MeHg} / \mathrm{THg}$ ratio that remained fairly constant throughout the flow regime at a given site but varied markedly among sites (Fig. 9). These constant ratios suggest that within each site, $\mathrm{THg}$ and $\mathrm{MeHg}$ have a common source. This source is likely to be hydrologically connected zones within these upland systems-wetlands, riparian areas, in-stream sediments - that sequester $\mathrm{THg}$ and provide an environment conducive to methylation. However, $\mathrm{THg}$ sources and $\mathrm{MeHg}$

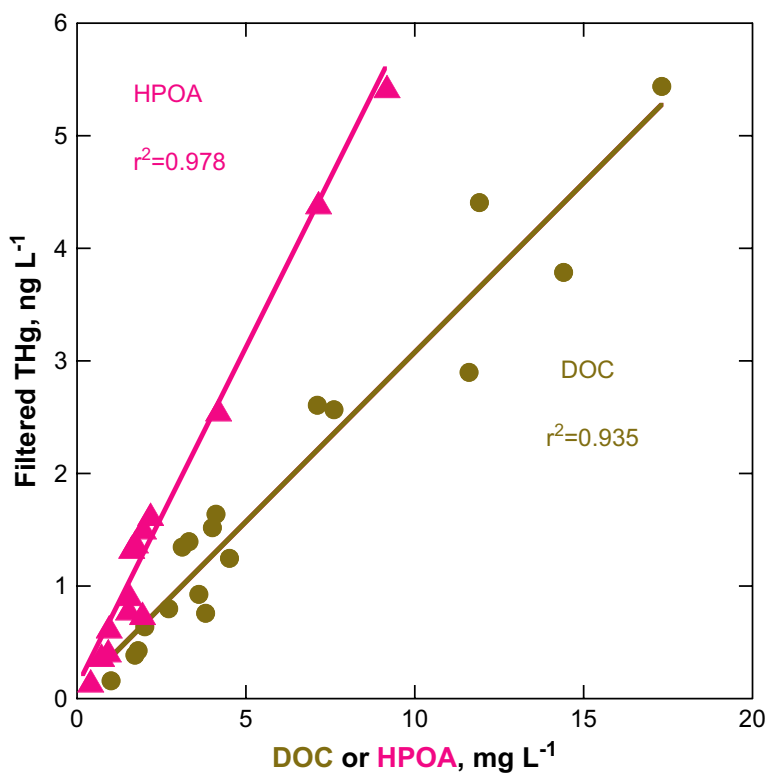

Fig. 8. Concentration of filtered THg vs. DOC and vs. the HPOA fraction of DOC at Sleepers River, VT. 


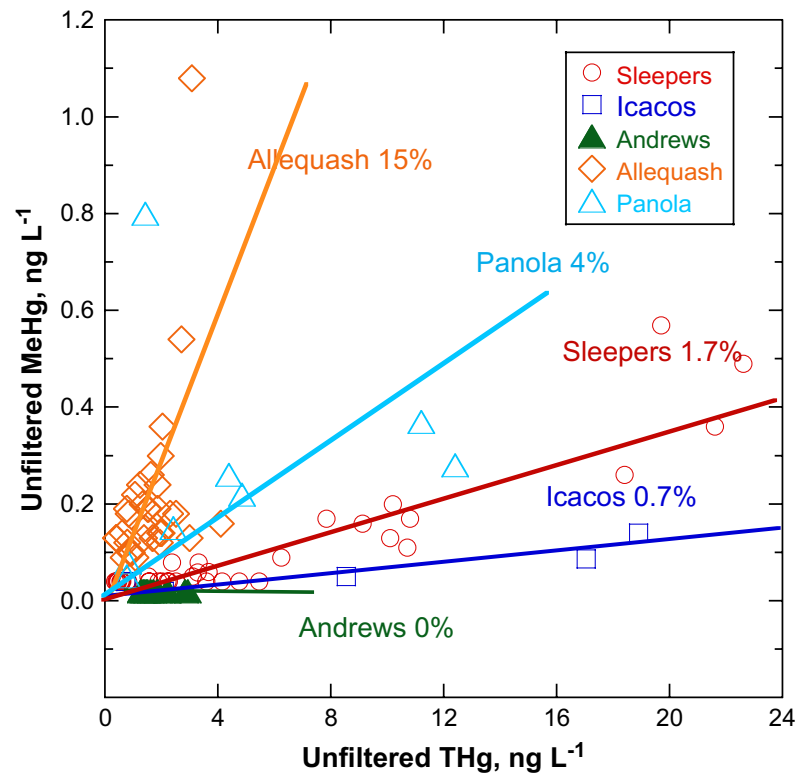

Fig. 9. Unfiltered MeHg vs. unfiltered $\mathrm{THg}$ at the five WEBB watersheds. The solid line and percentages for each site are not true regression lines, but are drawn to match the ratios from the calculated fluxes for each site. For Panola, where the relation has a great deal of scatter, the line was fitted approximately and forced through the origin.

production away from water body margins (Stoor et al., 2006) may also contribute to stream fluxes as these areas become hydrologically connected during large storm or snowmelt events. The constant $\mathrm{MeHg} / \mathrm{THg}$ ratios at each site are surprising given that $\mathrm{MeHg}$ concentrations typically vary seasonally (St. Louis et al., 1994; Babiarz et al., 1998; Schwesig and Matzner, 2001; Balogh et al., 2005; Selvendiran et al., 2008).

The percentage of $\mathrm{THg}$ as $\mathrm{MeHg}$ ranged from near $0 \%$ at Andrews to about $15 \%$ at Allequash (Fig. 9). These methylated percentages were inversely related to watershed slope; Andrews is the steepest catchment at $67 \%$ average slope while Allequash is a low-lying landscape with less than $1 \%$ average slope. The other three catchments each have average slopes near $20 \%$, and have intermediate $\mathrm{MeHg} / \mathrm{THg}$ ratios. Steep slopes tend to limit the amount of soil saturation and anoxia, and thus reduce potential for methylation, but other factors such as rainfall amount, $\mathrm{C}$ and $\mathrm{S}$ availability, and temperature may also be important factors.

At tropical Icacos, with annual rainfall $>4000 \mathrm{~mm}$, and soils at or near saturation year round, the low fraction of $\mathrm{MeHg}$ in streamwater ( $0.7 \%$ of $\mathrm{THg}$ flux) was surprising. We tested for limitations to methylation by analysis of organic sediment in tank bromeliads. Bromeliads are epiphytes on trees that receive nutrients only from rain and forest debris, often becoming anoxic with high DOC concentrations (Richardson et al., 2000), and thus represent a best-case scenario for methylation. The bromeliad water sample was roughly collinear with stream samples on the filtered $\mathrm{THg}$ vs. DOC plot (Fig. 7). Bromeliad sediment had $230 \mathrm{ng} \mathrm{THg}$ and $7 \mathrm{ng}$ $\mathrm{MeHg}$ per liter of slurry filtered, suggesting that there are no $\mathrm{Hg}, \mathrm{C}, \mathrm{S}$, or bacterial limitations to methylation in this ecosystem. One possibility for the low percentage of $\mathrm{MeHg}$ in streamwater is that demethylation rates are high.

\section{Conclusions}

We used the small watershed approach with an emphasis on high-flow sampling to investigate $\mathrm{THg}$ and $\mathrm{MeHg}$ cycling at the five geographically and climatically diverse USGS WEBB sites. Watershed processing of THg ranged widely, from $>96 \%$ retention (based on wet deposition and ignoring any subsequent volatilization) at low-relief Allequash Creek, WI, to net export at high-relief wet tropical Rio Icacos, Puerto Rico. At the two sites with greatest export, Icacos and Sleepers River, VT (60\% retention) and likely also at Panola Mountain in the Georgia Piedmont (annual fluxes not computed), Hg flux was dominated by episodic transport of particulate $\mathrm{THg}$ in association with POC at high flows. These three sites had more modest episodic fluxes of filtered $(<0.7 \mu \mathrm{m}) \mathrm{THg}$. THg export was lower but also episodic at Andrews Creek in the Colorado Rockies (83\% retention), but was dominated by filtered $\mathrm{THg}$ because POC was low. Filtered THg at these sites was strongly correlated with DOC, particularly the HPOA fraction of DOC.

$\mathrm{MeHg}$ behavior paralleled $\mathrm{THg}$ behavior to a surprising extent at most of the sites. Like $\mathrm{THg}$ flux, the particulate fraction dominated MeHg flux at Sleepers, Icacos, and Panola, and the filtered fraction dominated $\mathrm{MeHg}$ flux at Allequash. $\mathrm{MeHg}$ was below detection $\left(0.04 \mathrm{ng} \mathrm{L}^{-1}\right)$ at Andrews. The parallel patterns of $\mathrm{THg}$ and $\mathrm{MeHg}$ resulted in constant $\mathrm{MeHg} / \mathrm{THg}$ ratios at each site, ranging from near $0 \%$ at Andrews to $15 \%$ at Allequash. At Icacos, $\mathrm{MeHg}$ was only $0.7 \%$ of $\mathrm{THg}$, but the high $\mathrm{THg}$ flux resulted in $\mathrm{MeHg}$ flux that was an order of magnitude greater than that at Allequash.

Capturing $\mathrm{THg}$ and $\mathrm{MeHg}$ dynamics during high flow, when most of the flux occurs, provides insights into processes and better quantification of watershed retention than can be obtained from fixed interval sampling. Much of the previous upland mercury research has focused on boreal landscapes; we stress that processes in lower-DOC landscapes as represented by these five WEBB watersheds also result in the export of considerable $\mathrm{THg}$ and $\mathrm{MeHg}$.

\section{Acknowledgements}

This research was supported by the US Geological Survey Water, Energy, and Biogeochemical Budgets (WEBB) program. We thank John DeWild, Mark Olson, Shane Olund and the staff at the USGS Mercury Laboratory for prompt processing of time-sensitive samples, often on short notice. Thanks also to Barbara and Michael Richardson and Bill McDowell for suggestions and tips, and Doug Burns for field help with the bromeliad sampling. Eric Miller kindly provided output from his mercury deposition model specific to Sleepers. Thanks to Doug Burns, Mark Brigham, Kevin Bishop and an anonymous reviewer for helpful comments on an earlier version of this paper. Any use of trade, product, or firm names is for descriptive purposes only and does not imply endorsement by the U.S. Government. 


\section{References}

Aiken, G.R., McKnight, D.M., Thorn, K.A., Thurman, E.M., 1992. Isolation of hydrophilic acids from water using macroporous resins. Organic Geochemistry 18, 567-573.

Allan, C., Heyes, A., 1998. A preliminary assessment of wet deposition and episodic transport of total and methyl mercury from lower order Blue Ridge watersheds, SE USA. Water, Air, and Soil Pollution 105, 573-592.

Allan, C.J., Heyes, A., Roulet, N.T., St Louis, V.L., Rudd, J.W.M., 2001. Spatial and temporal dynamics of mercury in Precambrian Shield upland runoff. Biogeochemistry 52, 13-40.

Aulenbach, B.T., Hooper, R.P., 2006. The composite method: an improved method for stream-water solute load estimation. Hydrological Processes 14, 3029-3047.

Babiarz, C.L., Hurley, J.P., Benoit, J.M., Shafer, M.M., Andren, A.W., Webb, D.A., 1998. Seasonal influences on partitioning and transport of total and methylmercury in rivers from contrasting watersheds. Biogeochemistry 41, 237-257.

Babiarz, C.L., Hurley, J.P., Hoffman, S.R., Andren, A.W., Shafer, M.M., Armstrong, D.E., 2001. Partitioning of total mercury and methylmercury to the colloidal phase in freshwaters. Environmental Science \& Technology 35, 4773-4782.

Balcom, P.H., Fitzgerald, W.F., Vandal, G.M., Lamborg, C.H., Rolfhus, K.R., Langer, C.S., Hammerschmidt, C.R., 2004. Mercury sources and cycling in the Connecticut River and Long Island Sound. Marine Chemistry 90, 53-74.

Balogh, S.J., Meyer, M.L., Johnson, D.K., 1997. Mercury and suspended sediment loadings in the Lower Minnesota River. Environmental Science \& Technology 31, 198-202.

Balogh, S.J., Meyer, M., Johnson, K., 1998. Diffuse and point source mercury inputs to the Mississippi, Minnesota, and St. Croix Rivers. Science of the Total Environment 213, 109-113.

Balogh, S.J., Nollet, Y., Offerman, H.J., 2005. A comparison of total mercury and methylmercury export from various Minnesota watersheds. Science of the Total Environment 340, 261-270.

Benoit, J.M., Gilmour, C.C., Heyes, A., Mason, R.P., Miller, C.L., 2003. Geochemical and biological controls over methylmercury production and degradation in aquatic systems. In: Cai, Y., Braids, O.C. (Eds.), Biochemistry of Environmentally Important Trace Elements. American Chemical Society, Washington, DC, pp. 262-297.

Bishop, K., Lee, Y.H., Pettersson, C., Allard, B., 1995a. Methylmercury in runoff from the Svartberget Catchment in northern Sweden during a stormflow episode. Water, Air, and Soil Pollution 80, 221-224.

Bishop, K., Lee, Y.H., Pettersson, C., Allard, B., 1995b. Methylmercury output from the Svartberget Catchment in northern Sweden during spring flood. Water, Air, and Soil Pollution 80, 445-454.

Branfireun, B.A., Heyes, A., Roulet, N.T., 1996. The hydrology and methylmercury dynamics of a Precambrian Shield headwater peatland. Water Resources Research 32, 1785-1794.

Campbell, D.H., Clow, D.W., Ingersoll, G.P., Mast, M.A., Spahr, N.E., Turk, J.T., 1995. Processes controlling the chemistry of two snowmeltdominated streams in the Rocky Mountains. Water Resources Research 31, 2811-2821.

Cardona, W.A., 1984. El Junque mineral prospects, eastern Puerto Rico. Caribbean Journal of Science 20, 79-87.

Clow, D.W., Schrott, L., Webb, R., Campbell, D.H., Torizzo, A., Dornblaser, M., 2003. Ground water occurrence and contributions to streamflow in an alpine catchment, Colorado Front Range. Ground Water 41, 937-950.

DeWild, J.F., Olson, M.L., Olund, S.D., 2002. Determination of Methyl Mercury by Aqueous Phase Ethylation, Followed by Gas Chromatographic Separation with Cold Vapor Atomic Fluorescence Detection. US Geological Survey Open-File Report 01-445. US Geological Survey, Reston, VA, 13 pp.

Driscoll, C.T., Han, Y.-J., Chen, C.Y., Evers, D.C., Lambert, K.F., Holsen, T.M., Kamman, N.C., Munson, R.K., 2007. Mercury contamination in forest and freshwater ecosystems in the northeastern United States. BioScience 57, 17-28.
Evers, D.C., Han, Y.J., Driscoll, C.T., Kamman, N.C., Goodale, M.W., Lambert, K.F., Holsen, T.M., Chen, Y.C., Clair, T.A., Butler, T., 2007. Biological mercury hotspots in the northeastern United States and southeastern Canada. Bioscience 57, 29-43.

Gilmour, C.C., Riedel, G.S., Ederington, J.T., Bell, J.T., Benoit, J.M., Gill, G.A., Stordal, M.C., 1998. Methymercury concentrations and production rates across a trophic gradient in the northern Everglades. Biogeochemistry 40, 327-345.

Grigal, D.F., 2002. Inputs and outputs of mercury from terrestrial watersheds: a review. Environmental Reviews 10, 1-39.

Haitzer, M., Aiken, G.R., Ryan, J.N., 2002. Binding of mercury (II) to dissolved organic matter; the role of the mercury-to-DOM concentration ratio. Environmental Science \& Technology 36, 3564-3570.

Hall, B.D., St. Louis, V., 2004. Methylmercury and total mercury in plant litter decomposing in upland forests and flooded landscapes. Environmental Science \& Technology 38, 5010-5021.

Hall, B.D., Manolopoulos, H., Hurley, J.P., Schauer, J.J., St. Louis, V.L., Kenski, D., Graydon, J., Babiarz, C.L., Cleckner, L.B., Keeler, G.J., 2005. Methyl and total mercury in precipitation in the Great Lakes region. Atmospheric Environment 39, 7557-7569.

Hammerschmidt, C.R., Fitzgerald, W.F., 2004. Geochemical controls on the production and distribution of methylmercury in near-shore marine sediments. Environmental Science \& Technology 38, 1487-1495.

Harris, R.C., Rudd, J.W.M., Amyot, M., Babiarz, C.L., Beaty, K.G., Blanchfield, P.J., Bodaly, R.A., Branfireun, B.A., Gilmour, C.C., Graydon, J.A., Heyes, A., Hintelmann, H., Hurley, J.P., Kelly, C.A., Krabbenhoft, D.P., Lindberg, S.E., Mason, R.P., Paterson, M.J., Podemski, C.L., Robinson, A., Snadilands, K.A., Southworth, G.R., St. Louis, V.L., Tate, M.T., 2007. Whole-ecosystem study shows rapid fishmercury response to changes in mercury deposition. Proceedings of the National Academy of Sciences USA 104, 16586-16591.

Hurley, J., Benoit, J., Babiarz, C., Shafer, M., Andren, A., Sullivan, J., Hammond, R., Webb, D., 1995. Influence of watershed characteristics on mercury levels in Wisconsin rivers. Environmental Science \& Technology 29, 1867-1875.

Hurley, J.P., Cowell, S.E., Shafer, M., Huges, P.E., 1998a. Tributary loading of mercury to Lake Michigan: importance of seasonal events and phase partitioning. Science of the Total Environment 213, 129-137.

Hurley, J.P., Krabbenhoft, D.P., Cleckner, L.B., Olson, M.L., Aiken, G.R., Rawlik Jr., P.S., 1998b. System controls on the aqueous distribution of mercury in the northern Florida Everglades. Biogeochemistry 40, 293-310.

Kolka, R.K., Grigal, D.F., Verry, E.S., Nater, E.A., 1999. Mercury and organic carbon relationships in streams draining forested upland/peatland watersheds. Journal of Environmental Quality 28, 766-775.

Kolka, R.K., Grigal, D.F., Nater, E.A., Verry, E.S., 2001. Hydrologic cycling of mercury and organic carbon in a forested upland-bog watershed. Soil Science Society of America Journal 65, 897-905.

Krabbenhoft, D.P., Benoit, J.M., Babiarz, C.L., Hurley, J.P., Andren, A.W., 1995. Mercury cycling in the Allequash Creek Watershed, northern Wisconsin. Water, Air, and Soil Pollution 80, 425-433.

Krabbenhoft, D.P., Branfireun, B.A., Heyes, A., 2005. Biogeochemical cycles affecting the speciation, fate and transport of mercury in the environment. In: Parsons, M.B., Percival, J.B. (Eds.), Mercury: Sources, Measurements, Cycles, and Effects, Short Course Series, vol. 34. Mineralogical Association of Canada, Ottawa, pp. 139-156.

Larsen, M.C., Torres Sánchez, A.J., 1998. The frequency and distribution of recent landslides in three montane tropical regions of Puerto Rico. Geomorphology 24, 309-331.

Lee, Y.H., Bishop, K.H., Munthe, J., Iverfeldt, A., Verta, M., Parkman, H., Hultberg, H., 1998. An examination of current $\mathrm{Hg}$ deposition and export in Fenno-Scandian catchments. Biogeochemistry 40, 125-135.

Lewis, M.E., Brigham, M.E., 2004. Low-level mercury. In: Wilde, F.D., Radtke, D.B., Gibs, J., Iwatsubo, R.T. (Eds.), Processing of Water Samples. US Geological Survey Techniques of Water-Resources Investigations, Book 9, Chapter A5. US Geological Survey, Reston, VA.

Likens, G.E., Bormann, H.F., 1995. Biogeochemistry of a Forested Ecosystem, second ed.). Springer-Verlag, New York, 159 pp. 
Lins, H.F., 1994. Recent directions taken in water, energy, and biogeochemical budgets research. EOS. Transactions of the American Geophysical Union 75, 433-439.

Mast, M., Campbell, D., Krabbenhoft, D., Taylor, H., 2005. Mercury transport in a high-elevation watershed in Rocky Mountain National Park, Colorado. Water, Air, and Soil Pollution 164, 21-42.

Miller, E.K., Van Arsdale, A., Keeler, G.J., Chalmers, A., Poissant, L., Kamman, N.C., Brulotte, R., 2005. Estimation and mapping of wet and dry mercury deposition across northeastern North America. Ecotoxicology $14,53-70$.

Munthe, J., Hultberg, H., 2004. Mercury and methylmercury in runoff from a forested catchment - concentration, fluxes, and their response to manipulations. Water, Air, and Soil Pollution: Focus 4, 607-618.

Munthe, J., Bodaly, R.A., Branfireun, B.A., Driscoll, C.T., Gilmour, C.C., Harris, R., Horvat, M., Lucotte, M., Malm, O., 2007. Recovery of mercury-contaminated fisheries. Ambio 36, 33-44.

Nelson, S.J., Johnson, K.B., Kahl, J.S., Haines, T.A., Fernandez, I.J., 2007. Mass balances of mercury and nitrogen in burned and unburned forested watersheds at Acadia National Park, Maine, USA. Environmental Monitoring and Assessment 126, 69-80.

Olson, M.L., DeWild, J., 1999. Low-Level Collection Techniques and SpeciesSpecific Analytical Methods for Mercury in Water, Sediment, and Biota. US Geological Survey Water-Resources Investigations Report 99-4018b. US Geological Survey, Reston, VA.

Peters, N.E., 1989. Atmospheric deposition of sulfur to a granite outcrop in the piedmont of Georgia, USA. In: Delleur, J.W. (Ed.), International Association of Hydrology Scientific Publication 179, pp. 173-181.

Peters, N.E., Shanley, J.B., Aulenbach, B.T., Webb, R.M., Campbell, D.H., Hunt, R., Larsen, M.C., Stallard, R.F., Troester, J., Walker, J.F., 2006. Water and solute mass balance of five small, relatively undisturbed watersheds in the US. Science of the Total Environment 358, 221-242.

Porvari, P., Verta, M., Munthe, J., Haapanen, M., 2003. Forestry practices increase mercury and methylmercury output from boreal forest catchments. Environmental Science \& Technology 37, 2389-2393.

Quémerais, B., Cossa, D., Rondeau, B., Pham, T.T., Gagnon, P., Fortin, B., 1999. Sources and fluxes of mercury in the St. Lawrence River. Environmental Science \& Technology 33, 840-849.

Ravichandran, M., 2004. Interactions between mercury and dissolved organic matter: a review. Chemosphere 55, 319-331.

Richardson, B.A., Richardson, M.J., Scatena, F.N., McDowell, W.H., 2000. Effects of nutrient availability and other elevational changes on bromeliad populations and their invertebrate communities in a humid tropical forest in Puerto Rico. Journal of Tropical Ecology 16, 167-188.

St. Louis, V.L., Rudd, J.W.M., Kelly, C.A., Beaty, K.G., Bloom, N.S., Flett, R.J., 1994. Importance of wetlands as sources of methyl mercury to boreal forest ecosystems. Canadian Fisheries and Aquatic Science 51, 1065-1076.
St. Louis, V.L., Rudd, J.W.M., Kelly, C.A., Beaty, K.G., Robert, J.F., Roulet, N.T., 1996. Production and loss of methylmercury and loss of total mercury from boreal forest catchments containing different types of wetlands. Environmental Science \& Technology 30, 2719-2729.

St. Louis, V.L., Rudd, J.W.M., Kelly, C.A., Hall, B.D., Rolfhus, K.R., Scott, K.J., Lindberg, S.E., Dong, W., 2001. Importance of the forest canopy to fluxes of methyl mercury and total mercury to boreal ecosystems. Environmental Science \& Technology 35, 3089-3098.

Scherbatskoy, T., Shanley, J.B., Keeler, G.J., 1998. Factors controlling mercury transport in an upland forested catchment. Water, Air, and Soil Pollution 105, 427-438.

Schuster, P.F., Shanley, J.B., Reddy, M.M., Aiken, G.R., MarvinDiPasquale, M., Roth, D.A., Taylor, H.E., Krabbenhoft, D.P., Dewild, J.F., 2008. Mercury and organic carbon dynamics during runoff episodes from a northeastern USA watershed. Water, Air, and Soil Pollution 187, 89-108.

Schwesig, D., Matzner, E., 2001. Dynamics of mercury and methyl mercury in forest floor and runoff of a forested watershed in central Europe. Biogeochemistry 53, 181-200.

Selvendiran, P., Driscoll, C.T., Bushey, J.T., Montesdeoca, M.R., 2008. Wetland influence on mercury fate and transport in a temperate forested watershed. Environmental Pollution 154 (1), 46-55.

Shanley, J.B., Schuster, P.F., Reddy, M.M., Roth, D.A., Taylor, H.E., Aiken, G.R., 2002. Mercury on the move during snowmelt in Vermont. EOS. Transactions of the American Geophysical Union 83, 45-48.

Shanley, J.B., Krám, P., Hruška, J., Bullen, T.D., 2004. A biogeochemical comparison of two well-buffered catchments with contrasting histories of acid deposition. Water, Air, and Soil Pollution: Focus 4, 325-342.

Shanley, J.B., Troester, J.W., Krabbenhoft, D.P., Olson, M.L., 2006. High mercury deposition in the Luquillo Mountains, Puerto Rico. Abstracts, Eighth International Conference on Mercury as a Global Pollutant, August 6-11, 2006, Madison, WI, p. 58.

Stoor, R.W., Hurley, J.P., Babiarz, C.L., Armstrong, D.E., 2006. Subsurface sources of methyl mercury to Lake Superior from a wetland-forested watershed. Science of the Total Environment 368, 99-110.

Walker, J.F., Hunt, R.J., Bullen, T.D., Krabbenhoft, D.P., Kendall, C., 2003. Spatial and temporal variability of isotope and major ion chemistry in the Allequash Creek basin, northern Wisconsin. Ground Water 41, 883-902.

Wardsworth, F.H., 1949. The Development of the Forest Land Resources of the Luquillo Mountains of Puerto Rico. University of Michigan, Ann Arbor, MI, $480 \mathrm{pp}$.

White, A.F., Blum, A.E., Schulz, M.S., Vivit, D.V., Stonestrom, D.A., Larsen, M., Murphy, S.F., Eberl, D., 1998. Chemical weathering in a tropical watershed, Luquillo Mountains, Puerto Rico: I. Long-term versus short-term weathering fluxes. Geochimica et Cosmochimica Acta 62, 209-226. 